\title{
The Effect of Leadership and Motivation in Measuring Accountability Using the Calibrating Public Accountability Model (CPA Model)
}

\author{
Siti Kustinah ${ }^{1}$, Muhammad Anggionaldi ${ }^{2}$ \\ 1.2 General Achmad Yani University Cimahi, Indonesia \\ Email: siti.kustinah@lecture.unjani.ac.id
}

\begin{abstract}
The use of school aid funds (BOS) must be accounted for by the beneficiary schools. The performance of a school can be judged by how good the accountability of the school is. The principal plays an important role in realizing accountability in the school he leads. The principal's leadership and motivation are factors that can encourage the achievement of good school accountability. This study aims to determine the effect of leadership and motivation in measuring accountability using the CPA (Calibrating Public Accountability Model) measurement model. The research method used is quantitative verification. The population in this study were all school principals in West Bandung Regency and Cimahi City with the sample technique using a simple random technique. Data collection techniques using questionnaires. Data analysis technique using PLS. The results showed that there was an effect of leadership on accountability, while motivation had no effect on accountability. Simultaneously leadership and motivation affect accountability.
\end{abstract}

Keywords: Leadership, Motivation, Accountability.

\section{A. INTRODUCTION}

During the COVID-19 pandemic which has been going on since the beginning of 2020, the learning process is carried out using distance learning. Although the learning process is carried out online, the government continues to carry out its obligations to help smooth the learning process by continuing to provide School Operational Assistance (BOS). Reports on the use of BOS funds since 2020 have been carried out online by schools to the Ministry of Education and Culture Research and Technology through the official website of the Ministry of Education and Culture. This online reporting is expected to make it easier for schools to submit reports on the use of BOS funds as well as the use of online reporting as an effort to improve school discipline in submitting reports on the use of BOS funds so as to encourage the creation of accountability for financial reports in schools, because if in the first stage schools have not report the use of BOS funds, then the disbursement of the next stage cannot be carried out. The use of technology as a means of reporting is a good means of accountability because the public or the public can assess the use of these funds, this is in accordance with the statement put forward by (Hudaya et al., 2015) which states that accountability reports made available to the public through the website can encourage accountability. Minister of Education and Culture of the Republic of Indonesia Nadiem Makarim (July, 2020) increased the freedom of school principals to use School Operational Assistance funds to be followed by accountability and must achieve targets according to applicable principles and regulations. Based on data from 
the Ministry of Home Affairs, current actual conditions, funds BOS has not been managed in an orderly, efficient, effective and economical manner. (http://iaiglobal.or.id). Although the reporting of BOS funds has been done online, according to the Director General of PAUD, Basic Education and Secondary Education of the Ministry of Education and Culture, Ristek Jumeri (2021) said there are still schools that have not yet completed reporting on BOS funds. For the January 1-April 2021 stage, it has been distributed to 215,601 education units or $99.53 \%$ and there are still 102 units that have not received assistance due to inaccurate reports. For the 2nd stage in May-August 2021, 190,337 education units have been distributed or $87.87 \%$ and 26,266 or $13.3 \%$ have not been disbursed due to incomplete report data. (https://edukasi.kompas.com/read/2021/06/02). Based on data from the Ministry of Education in 2021 in phase 1 in West Bandung Regency it was recorded that $77 \%$ of schools had not reported the use of BOS funds and in Cimahi City there were $75 \%$ of schools.

Inaccuracy in reporting the use of BOS funds and other school funds, such as funds originating from donations from parents of students, should be reported in a timely manner because inaccuracies in reporting an organizational activity such as financial reporting can affect the performance of an organization, as well as schools as a public organization are highly demanded to be able to report and account for the use of their funds in a transparent and accountable manner. Communication of information in both the governmental and non-governmental or not-for-profit public sectors is important in creating accountability(Brender et al., 2017). Since 2020, reports on the use of BOS funds have been carried out directly by schools to the Ministry of Education and Culture, Research and Technology online through e-RKAS (e-Plan for School Budget Activities). The inaccuracy of financial reporting can be an indication of the lack of optimal accountability for financial reporting in schools, this not yet optimal achievement of accountability will clearly lead to a decrease in school performance in the long term. Financial accountability that has not been achieved optimally can be caused by the quality of human resources, especially the leadership and motivation of the person in charge of the budget. Leadership can encourage the achievement of accountability in an organization, especially public sector organizations. Leaders who have high attention to policies that have been set by the government will encourage their organizations to be accountable for all activities imposed on their organizations (Leithwood, 2002). The Director of Educational Personnel Development at the Directorate General of Teachers and Education Personnel of the Ministry of Education and Culture Santi Ambarukmi (2019) stated that the leadership of school principals needs to be strengthened so that the quality and performance of schools can improve. Furthermore, Santi said that in leading a school, the leader in this case the principal must have a high innovative spirit, master information technology well and be able to build partnerships with other parties, especially external parties. The school leader must be a school manager whose job is to improve the quality of the school. In addition to leadership, the motivation of school leaders or principals can also encourage the achievement of accountability for school 
financial reports.(Chen \& Hsieh, 2015). (Shillemans, 2016)stated that the measurement of accountability can be done using the Calibrating Public Accountability Model (CPA Model). This study aims to determine how the measurement of accountability using the CPA Model is influenced by leadership and motivation.

\section{B. LITERATURE REVIEW}

\section{Accountability}

Tokyo Declaration (Fadjar et al., 2020)The Guidelines for Public Accountability explain that accountability is the obligation of individuals who are trusted to manage public resources and those related to them, in order to answer matters relating to fiscal, managerial, and program or activity accountability in the form of a willingness to provide explanations and justifications for what has been said. they have done. Accountability is important to achieve effective performance especially in the public sector because elected officials or appointed officials need to show the public that they carry out their duties with the best responsibilities and use the available resources effectively and efficiently. In the public sector, Accountability means that all public officials must be able to answer citizens and report the correct use of their public resources. This is important because citizens or the public have access to facts or figures in the form of information that enables them to make decisions, thereby encouraging citizen participation in government. Democracy allows citizens to hold office in an accountable manner and also to monitor and control the behavior of stakeholders (Rufus \& O, 2019). Accountability consists of 2 types, namely vertical accountability and horizontal accountability. Vertical accountability is the accountability of the government (public sector) to the community, while horizontal accountability is the responsibility of the government (public sector) to institutions that are parallel to it.

In a well-functioning state, the government is subject to good accountability obtained from outside, for example from citizens (vertical), as well as accountability through public institutions empowered to oversee accountability or accountability (horizontally). This is in line with the statement put forward by (Tran \& Nguyen, 2020) which states that the participation of stakeholder institutions will be able to create the achievement of public accountability. Transparency is achieved by involving stakeholders in organizational activities (Cetindamar, 2018). Vertical accountability includes citizens acting through the electoral process or indirectly through civic organizations (civil society) or news media. Horizontal accountability includes various public entities created by the state to examine the abuse and ineffectiveness of its organizations (eg judiciary, auditor general, anti-corruption agency and Ombudsman).

According to (Grace, 2018) accountability as the obligation of a person or organizational unit to be responsible for the management and control of resources and implementation (Grace, 2018) said accountability means the obligation to account for what someone has done. Based on its function, accountability serves to provide information about decisions and actions taken during the organization's running, 
which allows outsiders to review the information and take corrective action as needed. To control and realize accountability is through information transparency (Wijaya et al., 2021). In the field of accounting, one of the information that needs to be presented transparently is financial statements.

Another dimension of accountability was put forward by (Han \& Perry, 2019) Five dimensions that represent employee accountability were obtained from a variety of multidisciplinary literature, including experimental psychology and public accountability research. These five dimensions are attributeability, observability, evaluability, answerability, and consequentiality. These five dimensions provide a theoretical basis for why employees feel responsible (such as feeling, belonging) and how accountability systems affect individuals. This study implies that the five dimensions are not conflicting typologies for achieving accountability but contribute to the overall accountability of employees, which are interwoven. cooperation of each dimension that gives value to the accountability function.

Achievement of optimal accountability must be designed properly so that it will be able to give birth to the practice of presenting quality reports, one of the models for developing accountability assessment is to use the CPA (Calibrating Public Accountability Model) model (Shillemans, 2016). In this study, an analysis ofmodel with consideration of aspects, namely two aspects of accountability time (accountability before decisions and accountability after decision making); two aspects relating to the relationship between the agency and its accountability forums (participating forums and non-participating forums); and two aspects related to assessment standards (Known standards and unknown standards) on which the agent or party responsible for the assessment is based.

\section{Leadership}

Leadership has been described by some experts as an action that influences other people or their subordinates to want to work together to achieve certain goals. (Edison, Emron et al., 2018). An explanation of several definitions of leadership as put forward by (Colquitt et al., 2019): "Leadership is defined as the use of power and influence to direct the activities of followers toward goal achievement. That direction can affect followers' interpretation of events, the organization of their work activities, their commitment to key goals, their relationships with other followers, or their access to cooperation and support from other work units".

Another definition put forward by (Robbins \& Timothy, 2018):“Leadership as the ability to influence a group toward the achievement of a vision or set of goals" (Dubrin \& Andrew J, 2019). Leadership is the ability to inspire confidence and support among the people on whose competence and commitment performance depends. Explains that leadership qualities can be viewed from two perspectives:

a. Cognitive skills mental abilities and knowledge.

b. Personality traits and characteristics have an important influence on leadership.

c. Effectiveness. 
Briefly and concisely (Colquitt et al., 2019) explains that the following five (5) leadership traits and their characteristics are as follows:

a. Awareness: Reliable, organized, reliable, ambitious, hard-working and diligent.

b. Compatibility: kind, cooperative, sympathetic, helpful, polite and warm.

c. Neuroticim: Nervous, moody, Emotional, Insecure, Jealous, Unstable.

d. Openness: Curious, Imaginative, Creative, Complex, Dispelled, Sophisticated.

e. Extrovert: Talkative, Friendly, Passionate, Assertive, Striking, (Dubrin \& Andrew J, 2019) Dominant.

The principal in a public organization is also required to act like a manager in a profit-oriented organization, namely the principal must have a proactive, innovative nature and must be brave in making or determining decisions because these characteristics will be able to affect organizational performance (Dwi Widyani et al., 2020). Another opinion expressed by (Dubrin \& Andrew J, 2019) states that the quality of a leader can be seen from two (2) important aspects, namely cognitive ability, in the process of leading they show imagination, creativity, and a willingness to experiment with methods or methods that have not been proven. The leader's ability to take appropriate corrective action can encourage the innovation ability of his subordinates (Zabolotniaia et al., 2019) and personality traits have an important influence on leadership effectiveness. Which traits and characteristics are most relevant should suit situations that may vary or differ. Through effective leadership encourages subordinates to be more enthusiastic in helping to solve organizational problems (Khuwaja et al., 2020). The principal in a public organization is also required to act like a manager in a profit-oriented organization, namely the principal must have a proactive, innovative nature and must be brave in making or determining decisions because these characteristics will be able to affect organizational performance (Dwi Widyani et al., 2020).

In this study, to strengthen the hypothesis proposed regarding the influence of leadership on financial accountability using Steawarship Theory (Donaldson \& Davis, 1991) This theory explains that managers or organizational implementers are not concerned with personal interests but prioritize the interests of the principal, in this theory it is explained that management has high honesty and integrity to be responsible to stakeholders and shareholders to maintain public trust. Regarding the research conducted in the school environment, it is clear that the principal in this case is the government or the head of the foundation, while the stakeholders in this study are parents or guardians of students.

Based on the previous explanation, it is known that financial accountability is a form of performance appraisal, especially managerial schools, so the concept of accountability uses the basic concept of performance. (Basil \& Kiriinya, 2019), (Widodo, 2017), (Butler, 2016), (Melo et al., 2020)] concluded that leadership is an important factor in creating organizational performance. Thus, some of the previous research that was used as a reference by researchers was research related to leadership on performance. (Hassan \& Hatmaker, 2016) conducted on public sector workers in 
the midwest of the United States, where the results of the research show that there is an influence of leadership on the performance of public sector employees. His other research is research conducted (Buyema, 2016) with a research sample of 195 managers who work at the Kenyan government action fund agency, the results of the study show that there is an influence of leadership on performance. Furthermore, research conducted by (Said et al., 2015) whose research results show that effective leadership will improve performance.

\section{Motivation}

Motivation comes from the Latin word movere which means encouragement, driving force or force that causes an action or deed. The word movere in English is often equated with motivation, which means giving motives, generating motives or things that cause encouragement or circumstances that cause encouragement (Suwatno \& Priansa, 2018). (Colquitt et al., 2019) motivation is defined as a set of energetic forces that originates both within and outside an employee, initiates workrelated effort, and determines its direction, intensity, and persistence. Motivation is a critical consideration because effective job performance often requires high levels of both ability and motivation. (Robbins \& Timothy, 2018) "We define motivation as the processes that account for an individual's intensity, direction, and persistence of effort toward attaining a goal.1 While general motivation is concerned with effort toward any goal, we'll narrow the focus to organizational goals."

David C. McClelland and colleagues have provided useful explanations of some of these needs. They have proposed a theory of motivation based on the premise that people acquire or learn to satisfy certain needs from their culture. The three key needs that drive employees are the need for achievement, power, and affiliation

1. The Need for Achievement

The need for achievement is the desire to achieve something that is difficult for oneself. People with a strong need for achievement are always thinking about how to do a job better, trying to find a job with high responsibility, trying to get ahead in their career.

2. The Need for Power

Leaders with a high need for power usually have a desire to control resources (for example, money and other assets) other than people.

3. The Need for Affiliate

The need for affiliation is the desire or need to establish and maintain good and warm relationships with other people, find ways to restore unfavorable relationships and reduce / calm a sad atmosphere, show adequate attention to the needs of others. This need theory makes an important contribution in identifying needs related to managerial performance.

Based on the previous explanation, it is known that accountability is a form of performance appraisal, so the concept of accountability uses the basic concept of performance, thus some previous studies that are used as references by researchers are research related to motivation towards performance. In general, several previous 
studies have shown that motivation has an effect on performance, such as the results of research (Kolk, Berend Van Der, 2019), (Miao et al., 2019), (Do et al., 2020), (Hutagalung, Riama Katarina, 2020), (Petrovsky et al., 2014), (Usman, 2017) Several related studies were used as references in this study, including research conducted by (Kolk, Berend Van Der, 2019) in subsequent studies explained that employee motivation plays one of the most important parts in organizational performance and confidently contributes to its development and prosperity. In this way, it is very important for every entrepreneur and manager to find out what really convinces employees to work hard and how to maximize organizational performance in general. Employee motivation is one of the most powerful and influential tools that can revive or awaken human resources. For increase or decrease (Abdi Muse, 2017). Apart from previous research, there is also an explanation that motivation has a significant influence on employee performance, this is due to motivation, and the stimulus felt by employees is very good. In addition, simultaneously motivation has a significant positive effect on employee performance. Because motivation has a very strong relationship with employee performance. Third, motivation on employee performance has a very strong interpretation (Usman, 2017), while increasing work motivation has a positive and significant effect on job satisfaction. One of the essential factors that causes humans to work is because they want to fulfill their needs. If the company meets the needs and expectations of its employees, what talents and skills they have, as well as opportunities for advancement and development, employees will feel satisfied in their work. If employees are satisfied then automatically they will work optimally so that their performance will increase (Pancasila, Irwan, 2020).

\section{METHODS}

Judging from the research objectives, the research in this study is a quantitative verification study. In this study, leadership consists of two dimensions that is Cognitive ability with indicators: imaginative, creative, and a willingness to experiment with unproven and dimensani methods or methods Personality Traits with indicators: self-awareness, self-confidence, proactive, and trustworthy. The dimension variable consists of three dimensions, namely the need for achievement with indicators of doing a good job, looking for a job with high responsibility, high attention to progress, the dimension of the need for power with indicators controlling resources. power, physical, controlling non-physical resources (employees), the desire to influence others, the desire to have an impact on others and dimensions Need for Affiliation: The need for friendship, the need for acceptance by the group, the need for cooperation, the need for security (avoiding conflict). Variable Accountability using the concept of model measurement Calibrating Public Accountability (CPA Model) with dimensions dimensions the indicator accountability time before and after the decision, dimension forum or assessment agency with indicators of official forums and participating forums and dimensions evaluation standard with standard process indicators and standard results. The data collection technique used questionnaires that were distributed and filled out by the principals as respondents. The population 
in this study were all school principals who worked in schools in West Bandung Regency and Cimahi City. The sampling technique used a simple random sample. To analyze the model in this study, the Partial Least Square (PLS) method will be used. Partial Least Square (PLS).

\section{RESULTS AND DISCUSSION}

Selection of research data is intended to determine whether the number of questionnaires distributed can be collected again in the same number, whether the returned questionnaires are complete and not in doubt. Questionnaires were distributed to 200 schools in West Bandung Regency and 50 schools in Cimahi City. Based on these data, not all schools were willing to fill out the questionnaires distributed, so the number of respondents who were willing to fill out the questionnaires was only 113 schools with the following details:

\section{Results of Model Analysis and Hypothesis Testing}

This study analyzes the model using two evaluation models, namely assessing the outer model or measurement model and the inner model or structural model. The outer model or measurement model uses convergent validity, average variance extracted, discriminant validity, and composite reliability tests. The inner model or structural model uses the R-squared (R2) test and the path coefficient estimation test. Table 1 Convergent Validity Test Results Leadership variable (Dimensional level)

\begin{tabular}{|c|c|c|c|c|}
\hline Dimension & Indicator & $\begin{array}{c}\text { Original } \\
\text { Sample (O) }\end{array}$ & stipulation & Description \\
\hline \multirow{3}{*}{$\begin{array}{l}\text { Cognitive } \\
\text { ability }\end{array}$} & Imaginative & 0.764 & 0.6 & Valid \\
\hline & creative & 0.779 & 0.6 & Valid \\
\hline & Willingness to experiment & 0.832 & 0.6 & Valid \\
\hline \multirow{17}{*}{$\begin{array}{c}\text { Personality } \\
\text { Traits }\end{array}$} & Reliable & 0.800 & 0.6 & Valid \\
\hline & Organized & 0.722 & 0.6 & Valid \\
\hline & Ambitious & 0.737 & 0.6 & Valid \\
\hline & Hard work & 0.791 & 0.6 & Valid \\
\hline & Persistent & 0.828 & 0.6 & Valid \\
\hline & Good & 0.805 & 0.6 & Valid \\
\hline & cooperative & 0.796 & 0.6 & Valid \\
\hline & Sympathetic & 0.717 & 0.6 & Valid \\
\hline & Beneficial & 0.800 & 0.6 & Valid \\
\hline & Polite & 0.739 & 0.6 & Valid \\
\hline & Warm & 0.724 & 0.6 & Valid \\
\hline & Talk too much & 0.824 & 0.6 & Valid \\
\hline & Friendly & 0.728 & 0.6 & Valid \\
\hline & Spirit & 0.748 & 0.6 & Valid \\
\hline & Firm & 0.782 & 0.6 & Valid \\
\hline & Dominant & 0.719 & 0.6 & Valid \\
\hline & Empathy & 0.807 & 0.6 & Valid \\
\hline
\end{tabular}

Source: Data processed in 2021

Based on the table above, the lowest outer loading value is 0.717 (which is a sympathetic indicator in the personality trait dimension) and the highest outer 
loading value is 0.832 (i.e. an indicator of willingness to experiment in the cognitive ability dimension), because all indicators have an outer loading value greater than 0 . ,6 so it can be concluded that all of these indicators are valid.

Table 2 Convergent Validity Test Results Motivation variable (Dimensional level)

\begin{tabular}{|c|c|c|c|c|}
\hline Dimension & Indicator & $\begin{array}{c}\text { Original } \\
\text { Sample (O) }\end{array}$ & stipulation & Description \\
\hline \multirow{3}{*}{$\begin{array}{c}\text { Need for } \\
\text { Achievements }\end{array}$} & Good Job Needs & 0.818 & 0.6 & Valid \\
\hline & Responsible Job Needs & 0.849 & 0.6 & Valid \\
\hline & The need to advance & 0.878 & 0.6 & Valid \\
\hline \multirow{4}{*}{$\begin{array}{l}\text { Need for } \\
\text { Power }\end{array}$} & $\begin{array}{c}\text { The need to control physical } \\
\text { resources }\end{array}$ & 0.782 & 0.6 & Valid \\
\hline & $\begin{array}{l}\text { The need to control non-physical } \\
\text { resources }\end{array}$ & 0.813 & 0.6 & Valid \\
\hline & Need to Influence others & 0.808 & 0.6 & Valid \\
\hline & $\begin{array}{l}\text { The need to have an impact on } \\
\text { others }\end{array}$ & 0.746 & 0.6 & Valid \\
\hline \multirow{3}{*}{$\begin{array}{l}\text { Need for } \\
\text { affiliation }\end{array}$} & The need for friendship & 0.873 & 0.6 & Valid \\
\hline & $\begin{array}{l}\text { The need to be accepted in the } \\
\text { group }\end{array}$ & 0.848 & 0.6 & Valid \\
\hline & Need for security & 0.872 & 0.6 & Valid \\
\hline
\end{tabular}

Source: Data processed in 2021

Based on the table above, the lowest outer loading value is 0.746 (i.e. the indicator of need has an impact on others in the need for power dimension) and the highest outer loading value is 0.878 (i.e. the indicator of the need to advance in the need for achievement dimension), because all indicators have outer loading value is greater than 0.6 so it can be concluded that all of these indicators are valid. Thus, it can be concluded that all indicators in the Motivation variable can be said to be valid for further analysis.

Table 3 Convergent Validity Test Results Accountability variable (Dimensional level)

\begin{tabular}{|c|c|c|c|c|}
\hline \multirow{2}{*}{ Dimension } & Indicator & $\begin{array}{c}\text { Original } \\
\text { Sample (O) }\end{array}$ & stipulation & Description \\
\hline \multirow{2}{*}{$\begin{array}{c}\text { Accountability } \\
\text { time }\end{array}$} & Before decision & 0.897 & 0.6 & Valid \\
\cline { 2 - 5 } & After decision & 0.897 & 0.6 & Valid \\
\hline \multirow{2}{*}{ Rating Forum } & Official Forum & $\mathbf{0 . 9 1 1}$ & 0.6 & Valid \\
\cline { 2 - 5 } & Participating forums & $\mathbf{0 . 8 7 8}$ & 0.6 & Valid \\
\hline \multirow{2}{*}{$\begin{array}{c}\text { Evaluation } \\
\text { Standard }\end{array}$} & Process Standard & 0.900 & 0.6 & Valid \\
\cline { 2 - 5 } & Yield standard & 0.890 & 0.6 & Valid \\
\hline
\end{tabular}

Source: Data processed in 2021

Based on the table above, the lowest outer loading value is 0.878 (that is, the forum indicator participates in the assessment forum dimension) and the highest outer loading value is 0.911 (ie the official forum indicator in the assessor forum dimension), because all indicators have an outer loading value greater than 0.6 so it can be concluded that all of these indicators are valid. Thus, it can be concluded that all indicators in the Accountability variable can be said to be valid for further analysis. 
Table 4 Convergent Validity Test Results Leadership variable (variable level)

\begin{tabular}{|c|c|c|c|c|}
\hline Variable & Indicator & $\begin{array}{c}\text { Original } \\
\text { Sample (O) }\end{array}$ & stipulation & Description \\
\hline \multirow{20}{*}{ Leadership } & Imaginative & 0.643 & 0.6 & Valid \\
\hline & creative & 0.609 & 0.6 & Valid \\
\hline & Willingness to experiment & 0.706 & 0.6 & Valid \\
\hline & Reliable & 0.784 & 0.6 & Valid \\
\hline & Organized & 0.727 & 0.6 & Valid \\
\hline & Ambitious & 0.733 & 0.6 & Valid \\
\hline & Hard work & 0.795 & 0.6 & Valid \\
\hline & Persistent & 0.819 & 0.6 & Valid \\
\hline & Good & 0.798 & 0.6 & Valid \\
\hline & cooperative & 0.722 & 0.6 & Valid \\
\hline & Sympathetic & 0.798 & 0.6 & Valid \\
\hline & Beneficial & 0.723 & 0.6 & Valid \\
\hline & Polite & 0.720 & 0.6 & Valid \\
\hline & Warm & 0.820 & 0.6 & Valid \\
\hline & Talk too much & 0.730 & 0.6 & Valid \\
\hline & Friendly & 0.747 & 0.6 & Valid \\
\hline & Spirit & 0.773 & 0.6 & Valid \\
\hline & Firm & 0.713 & 0.6 & Valid \\
\hline & Dominant & 0.795 & 0.6 & Valid \\
\hline & Empathy & 0.807 & 0.6 & Valid \\
\hline
\end{tabular}

Source: Data processed in 2021

Based on the table above, the lowest outer loading value is 0.609 (ie creative indicator) and the highest outer loading value is 0.820 (ie warm indicator), because all indicators have an outer loading value greater than 0.6 so it can be concluded that all these indicators is valid.

Table 5 Convergent Validity Test Results Motivation variable (variable level)

\begin{tabular}{|c|c|c|c|c|}
\hline \multirow{4}{*}{ Variable } & Indicator & $\begin{array}{c}\text { Original } \\
\text { Sample } \\
\mathbf{( O )}\end{array}$ & stipulation & Description \\
\hline \multirow{5}{*}{} & Good job requirement & 0.743 & 0.6 & Valid \\
\cline { 2 - 5 } & Responsible Job Needs & 0.773 & 0.6 & Valid \\
\cline { 2 - 5 } & The need to advance & $\mathbf{0 . 8 5 3}$ & 0.6 & Valid \\
\cline { 2 - 5 } & The need to control physical resources & 0.719 & 0.6 & Valid \\
\cline { 2 - 5 } & The need to control non-physical resources & $\mathbf{0 . 7 1 4}$ & 0.6 & Valid \\
\cline { 2 - 5 } & Need to Influence others & 0.722 & 0.6 & Valid \\
\cline { 2 - 5 } & Needs have an impact on others & 0.756 & 0.6 & Valid \\
\cline { 2 - 5 } & The need for friendship & 0.816 & 0.6 & Valid \\
\cline { 2 - 5 } & The need to be accepted in the group & 0.817 & 0.6 & Valid \\
\cline { 2 - 5 } & Need for security & 0.784 & 0.6 & Valid \\
\hline
\end{tabular}

Source: Data processed in 2021

Based on the table above, the lowest outer loading value is 0.714 (that is, an indicator of the need to control physical resources) and the highest value of outer loading is 0.853 (which is an indicator of the need to advance), because all indicators have an outer loading value greater than 0.6 so that it can be concluded that all of these indicators are valid. 
Table 6 Convergent Validity Test Results Accountability variable (variable level)

\begin{tabular}{|c|c|c|c|c|}
\hline \multirow{2}{*}{ Variable } & Indicator & $\begin{array}{c}\text { Original } \\
\text { Sample (O) }\end{array}$ & stipulation & Description \\
\hline \multirow{4}{*}{ Accountability } & Before decision & 0.724 & 0.6 & Valid \\
\cline { 2 - 5 } & After decision & $\mathbf{0 . 7 2 2}$ & 0.6 & Valid \\
\cline { 2 - 5 } & Official Forum & $\mathbf{0 . 8 6 9}$ & 0.6 & Valid \\
\cline { 2 - 5 } & Participating forums & 0.748 & 0.6 & Valid \\
\cline { 2 - 5 } & Process Standard & 0.801 & 0.6 & Valid \\
\cline { 2 - 5 } & Yield standard & 0.766 & 0.6 & Valid \\
\hline
\end{tabular}

Source: Data processed in 2021

Based on the table above, the lowest outer loading value is 0.722 (that is, the indicator after the decision) and the highest outer loading value is 0.869 (i.e. the official forum indicator), because all indicators have an outer loading value greater than 0.6 so it can be concluded that all the indicator is valid. Thus, it can be concluded that all indicators in the Accountability variable can be said to be valid for further analysis.

\section{Discriminant Validity Test}

Discriminant validity is calculated using cross loading which aims to determine whether the construct has an adequate discriminant, namely with the criteria that the loading value of the intended construct must be greater than the value of loading with other constructs. Thus, the indicator is declared valid in measuring the appropriate dimensions/variables.

Table 7 Cross Loading Discriminant Validity Test Results at the dimension level

\begin{tabular}{|c|c|c|c|c|c|c|c|c|c|}
\hline & $\mathrm{X} 1$ & $\mathrm{X} 2$ & X3 & $\mathrm{X} 4$ & $\mathrm{X} 5$ & Y1 & $\mathrm{Y} 2$ & Y3 & Max \\
\hline K1 & 0.764 & 0.598 & 0.382 & 0.372 & 0.422 & 0.199 & 0.219 & 0.222 & 0.764 \\
\hline $\mathrm{K} 2$ & 0.779 & 0.558 & 0.317 & 0.239 & 0.260 & -0.066 & 0.032 & 0.148 & 0.779 \\
\hline K3 & 0.832 & 0.660 & 0.367 & 0.340 & 0.327 & 0.129 & 0.107 & 0.115 & 0.832 \\
\hline K4 & 0.545 & 0.800 & 0.350 & 0.286 & 0.288 & 0.196 & 0.270 & 0.261 & 0.800 \\
\hline K5 & 0.610 & 0.722 & 0.440 & 0.366 & 0.436 & 0.244 & 0.154 & 0.213 & 0.722 \\
\hline K6 & 0.562 & 0.737 & 0.436 & 0.378 & 0.307 & 0.145 & 0.234 & 0.320 & 0.737 \\
\hline K7 & 0.657 & 0.791 & 0.488 & 0.418 & 0.387 & 0.140 & 0.237 & 0.301 & 0.791 \\
\hline K8 & 0.612 & 0.828 & 0.320 & 0.247 & 0.230 & 0.297 & 0.327 & 0.191 & 0.828 \\
\hline K9 & 0.592 & 0.805 & 0.361 & 0.287 & 0.269 & 0.286 & 0.282 & 0.329 & 0.805 \\
\hline K10 & 0.634 & 0.796 & 0.396 & 0.278 & 0.266 & 0.157 & 0.262 & 0.208 & 0.796 \\
\hline K11 & 0.585 & 0.717 & 0.370 & 0.254 & 0.358 & 0.282 & 0.421 & 0.527 & 0.717 \\
\hline K12 & 0.628 & 0.800 & 0.358 & 0.335 & 0.308 & 0.220 & 0.235 & 0.271 & 0.800 \\
\hline K13 & 0.476 & 0.739 & 0.317 & 0.275 & 0.333 & 0.353 & 0.395 & 0.435 & 0.739 \\
\hline K14 & 0.555 & 0.724 & 0.365 & 0.369 & 0.357 & 0.190 & 0.283 & 0.243 & 0.724 \\
\hline K15 & 0.637 & 0.824 & 0.427 & 0.362 & 0.351 & 0.167 & 0.206 & 0.243 & 0.824 \\
\hline K16 & 0.593 & 0.728 & 0.321 & 0.250 & 0.255 & 0.092 & 0.283 & 0.295 & 0.728 \\
\hline K17 & 0.588 & 0.748 & 0.305 & 0.192 & 0.315 & 0.141 & 0.237 & 0.255 & 0.748 \\
\hline K18 & 0.570 & 0.782 & 0.367 & 0.279 & 0.278 & 0.255 & 0.278 & 0.332 & 0.782 \\
\hline K19 & 0.533 & 0.719 & 0.208 & 0.236 & 0.224 & 0.218 & 0.322 & 0.312 & 0.719 \\
\hline K20 & 0.642 & 0.807 & 0.447 & 0.372 & 0.365 & 0.253 & 0.381 & 0.353 & 0.807 \\
\hline M1 & 0.303 & 0.399 & 0.818 & 0.661 & 0.598 & 0.189 & 0.229 & 0.322 & 0.818 \\
\hline M2 & 0.481 & 0.442 & 0.849 & 0.620 & 0.704 & 0.056 & 0.074 & 0.184 & 0.849 \\
\hline M3 & 0.360 & 0.386 & 0.878 & 0.718 & 0.792 & 0.217 & 0.273 & 0.344 & 0.878 \\
\hline M4 & 0.261 & 0.243 & 0.595 & 0.782 & 0.621 & 0.116 & -0.005 & 0.068 & 0.782 \\
\hline M5 & 0.344 & 0.279 & 0.546 & 0.813 & 0.621 & 0.130 & 0.037 & 0.094 & 0.813 \\
\hline M6 & 0.217 & 0.289 & 0.624 & 0.808 & 0.567 & 0.239 & 0.253 & 0.241 & 0.808 \\
\hline M7 & 0.440 & 0.432 & 0.705 & 0.746 & 0.652 & 0.129 & 0.224 & 0.324 & 0.746 \\
\hline
\end{tabular}




\begin{tabular}{|l|l|l|l|l|l|l|l|l|l|} 
M8 & 0.410 & 0.352 & 0.674 & 0.731 & 0.873 & 0.239 & 0.217 & 0.349 & $\mathbf{0 . 8 7 3}$ \\
\hline M9 & 0.410 & 0.408 & 0.776 & 0.663 & 0.848 & 0.228 & 0.183 & 0.318 & $\mathbf{0 . 8 4 8}$ \\
\hline M10 & 0.280 & 0.291 & 0.693 & 0.633 & 0.872 & 0.072 & 0.024 & 0.175 & $\mathbf{0 . 8 7 2}$ \\
\hline A1 & 0.072 & 0.198 & 0.192 & 0.223 & 0.201 & 0.897 & 0.539 & 0.472 & $\mathbf{0 . 8 9 7}$ \\
\hline A2 & 0.135 & 0.300 & 0.136 & 0.126 & 0.175 & 0.897 & 0.543 & 0.460 & $\mathbf{0 . 8 9 7}$ \\
\hline A3 & 0.144 & 0.335 & 0.216 & 0.235 & 0.197 & 0.560 & 0.911 & 0.766 & $\mathbf{0 . 9 1 1}$ \\
\hline A4 & 0.127 & 0.320 & 0.191 & 0.044 & 0.091 & 0.516 & 0.878 & 0.532 & $\mathbf{0 . 8 7 8}$ \\
\hline A5 & 0.134 & 0.302 & 0.273 & 0.214 & 0.283 & 0.483 & 0.682 & 0.900 & $\mathbf{0 . 9 0 0}$ \\
\hline A6 & 0.230 & 0.392 & 0.329 & 0.204 & 0.302 & 0.447 & 0.632 & 0.890 & $\mathbf{0 . 8 9 0}$ \\
\hline
\end{tabular}

Source: Data processed in 2021

The table above describes the value of cross loading for each indicator against its own dimensions as well as against other dimensions. the number in blue indicates the cross loading value of the dimensions. Based on the table, it can be seen thateach indicator has a higher cross loading value on its own dimensions compared to other dimensions so that it can be concluded that all indicators meet the requirements of discriminant validity.

Table 8 Cross Loading Discriminant Validity Test Results at the variable level

\begin{tabular}{|c|c|c|c|c|}
\hline Indicator & Leadership & Motivation & Accountability & Max \\
\hline Imaginative & 0.643 & 0.421 & 0.247 & 0.643 \\
\hline creative & 0.609 & 0.291 & 0.048 & 0.609 \\
\hline Willingness to experiment & 0.706 & 0.370 & 0.135 & 0.706 \\
\hline Reliable & 0.784 & 0.330 & 0.282 & 0.784 \\
\hline Organized & 0.727 & 0.443 & 0.234 & 0.727 \\
\hline Ambitious & 0.733 & 0.401 & 0.273 & 0.733 \\
\hline Hard work & 0.795 & 0.462 & 0.265 & 0.795 \\
\hline Persistent & 0.819 & 0.285 & 0.314 & 0.819 \\
\hline Good & 0.798 & 0.327 & 0.346 & 0.798 \\
\hline cooperative & 0.795 & 0.335 & 0.244 & 0.795 \\
\hline Sympathetic & 0.722 & 0.350 & 0.479 & 0.722 \\
\hline Beneficial & 0.798 & 0.359 & 0.280 & 0.798 \\
\hline Polite & 0.723 & 0.330 & 0.457 & 0.723 \\
\hline Warm & 0.720 & 0.391 & 0.278 & 0.720 \\
\hline Talk too much & 0.820 & 0.408 & 0.239 & 0.820 \\
\hline Friendly & 0.730 & 0.295 & 0.263 & 0.730 \\
\hline Spirit & 0.747 & 0.289 & 0.247 & 0.747 \\
\hline Firm & 0.773 & 0.330 & 0.334 & 0.773 \\
\hline Dominant & 0.713 & 0.240 & 0.331 & 0.713 \\
\hline Empathy & 0.807 & 0.423 & 0.384 & 0.807 \\
\hline Good job requirement & 0.397 & 0.743 & 0.287 & 0.743 \\
\hline Responsible Job Needs & 0.462 & 0.773 & 0.123 & 0.773 \\
\hline The need to advance & 0.395 & 0.853 & 0.323 & 0.853 \\
\hline $\begin{array}{l}\text { The need to control physical } \\
\text { resources }\end{array}$ & 0.253 & 0.719 & 0.066 & 0.719 \\
\hline $\begin{array}{l}\text { The need to control non- } \\
\text { physical resources }\end{array}$ & 0.297 & 0.714 & 0.099 & 0.714 \\
\hline Need to Influence others & 0.287 & 0.722 & 0.282 & 0.722 \\
\hline $\begin{array}{l}\text { Needs have an impact on } \\
\text { others }\end{array}$ & 0.447 & 0.756 & 0.264 & 0.756 \\
\hline The need for friendship & 0.373 & 0.816 & 0.311 & 0.816 \\
\hline $\begin{array}{l}\text { The need to be accepted in the } \\
\text { group }\end{array}$ & 0.422 & 0.817 & 0.281 & 0.817 \\
\hline Need for security & 0.298 & 0.784 & 0.104 & 0.784 \\
\hline Before decision & 0.185 & 0.222 & 0.724 & 0.724 \\
\hline
\end{tabular}




\begin{tabular}{|l|c|c|c|c|} 
After decision & 0.285 & 0.157 & 0.722 & $\mathbf{0 . 7 2 2}$ \\
\hline Official Forum & 0.317 & 0.234 & 0.869 & $\mathbf{0 . 8 6 9}$ \\
\hline Participating forums & 0.301 & 0.115 & 0.748 & $\mathbf{0 . 7 4 8}$ \\
\hline Process Standard & 0.287 & 0.276 & 0.801 & $\mathbf{0 . 8 0 1}$ \\
\hline Yield standard & 0.381 & 0.297 & 0.766 & $\mathbf{0 . 7 6 6}$ \\
\hline
\end{tabular}

Source: Data processed in 2021

The table above describes the value of cross loading for each indicator on its own variables and on other variables. the number in blue indicates the cross loading value of the variable. Based on the table, it can be seen that the indicator each indicator has a higher cross loading value on its own variable compared to other variables so that it can be concluded that all indicators meet the requirements of discriminant validity.

\section{Reliability Test}

Reliability test can be done by using Cronbach's alpha and composite reliability. The test criteria state that if the composite reliability is greater than 0.7 and Cronbach's alpha is greater than 0.6 then the construct is declared reliable.

Table 9 Reliability Test Results

\begin{tabular}{|c|l|c|c|}
\hline \multirow{2}{*}{ Level } & Cronbach's & $\begin{array}{c}\text { Composite } \\
\text { Alpha } \\
\text { Reliability }\end{array}$ \\
\hline \multirow{4}{*}{ Variable } & Accountability & 0.865 & 0.899 \\
\cline { 2 - 4 } & Leadership & 0.959 & 0.962 \\
\cline { 2 - 4 } & Motivation & 0.924 & 0.936 \\
\hline \multirow{5}{*}{ Dimensions' } & Cognitive ability & 0.703 & 0.835 \\
\cline { 2 - 4 } & Personality Traits & 0.957 & 0.961 \\
\cline { 2 - 4 } & Need for Achievements & 0.806 & 0.885 \\
\cline { 2 - 4 } & Need for power & 0.796 & 0.867 \\
\cline { 2 - 4 } & Need for Affiliate & 0.831 & 0.899 \\
\cline { 2 - 4 } & Accountability time & 0.758 & 0.892 \\
\cline { 2 - 4 } & Rating forum & 0.751 & 0.889 \\
\cline { 2 - 4 } & Evaluation standard & 0.751 & 0.889 \\
\hline
\end{tabular}

Source: Data processed in 2021

Based on the table, it can be seen that each variable and dimension produces Cronbach's alpha value greater than 0.6 and composite reliability value greater than 0.7. Thus, based on the calculation of the value of Chronbach's alpha and the value of composite reliability, all indicators are declared reliable in measuring the variables.

\section{Inner Model Evaluation}

Evaluation of the inner model or structural model is a step to evaluate the goodness of fit which includes the coefficient of determination and hypothesis testing. The structural model of the research can be seen in the following figure: 


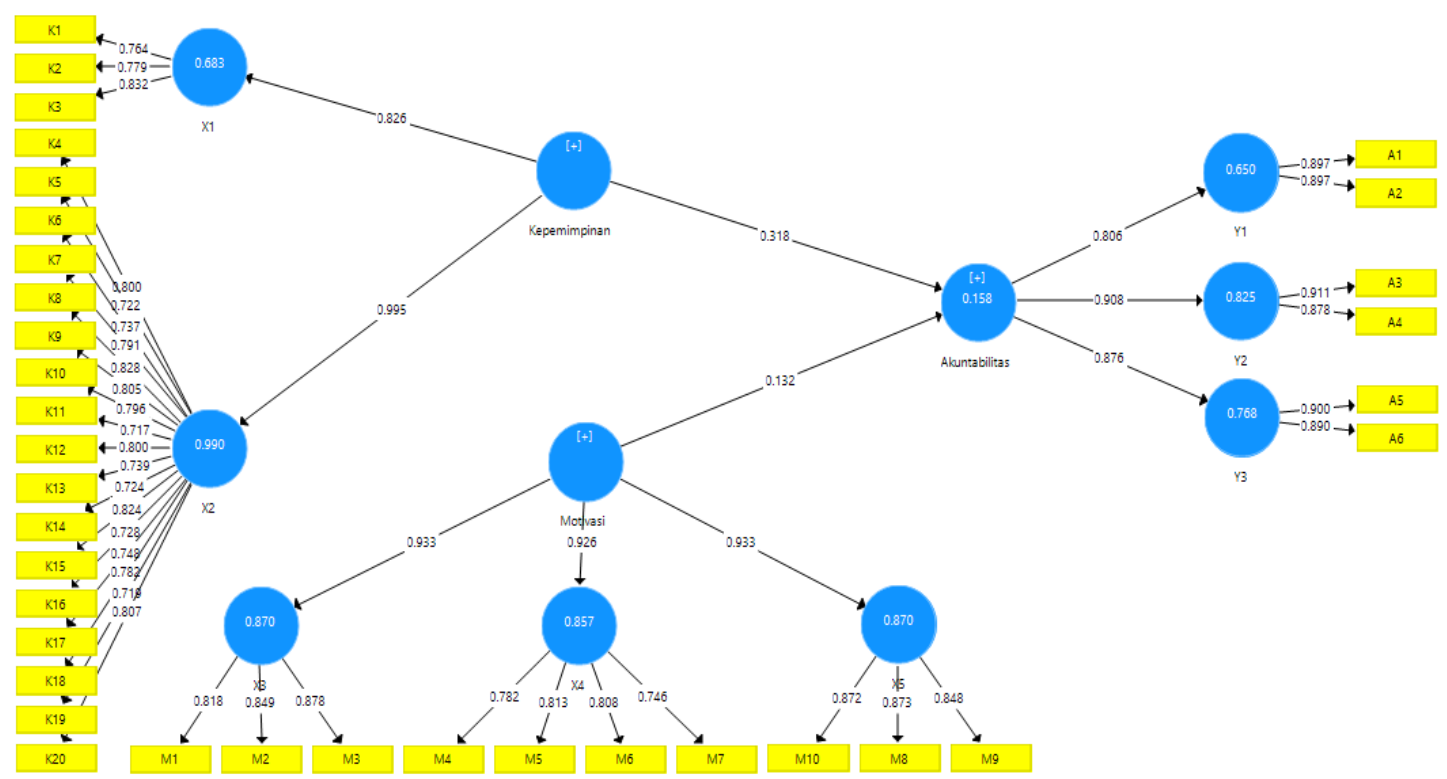

Figure 1 Standardized Models

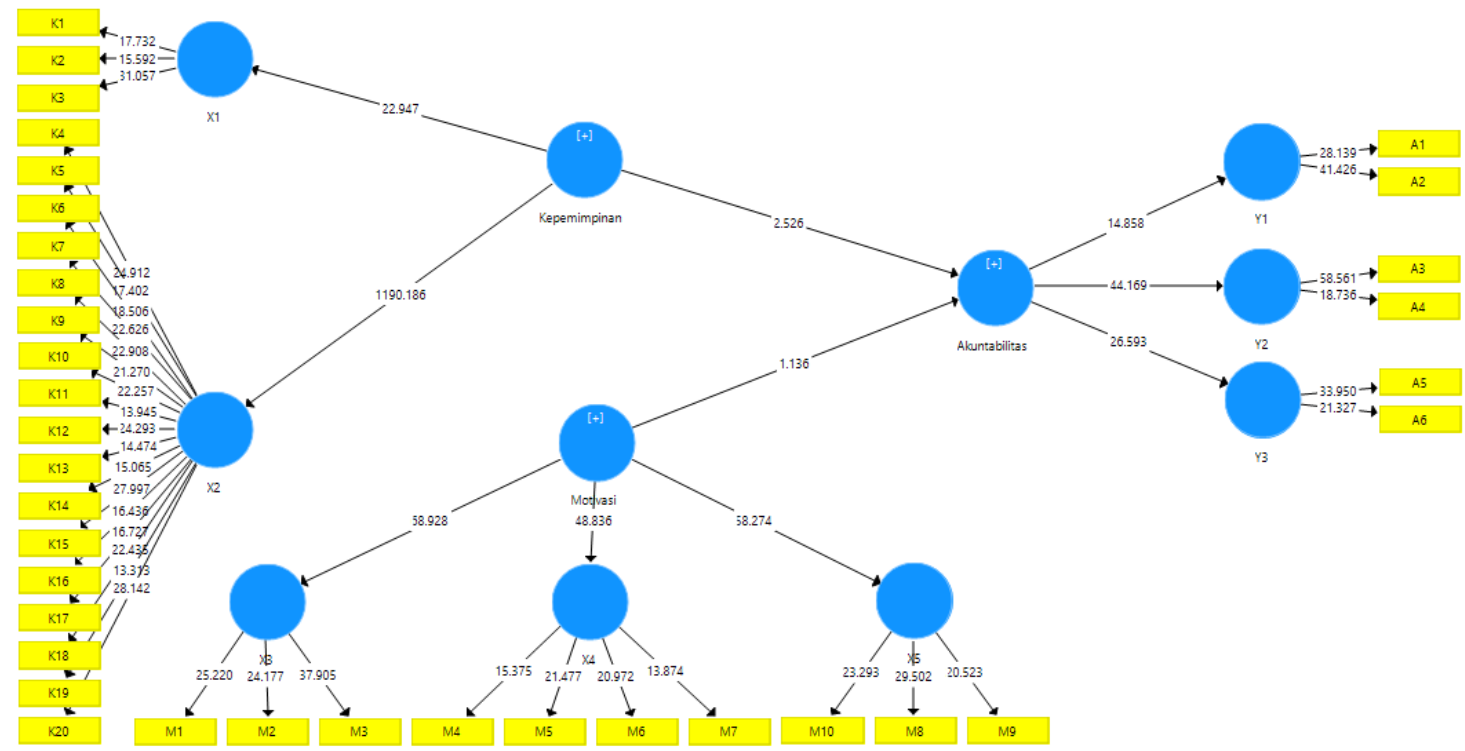

Figure 2 Model $t$-value

\section{Regression Equation}

Based on the picture above, the equation obtained is as follows: Accountability $=0.318$ Leadership +0.132 Motivation, $\mathrm{R} 2=0.158$. Based on these equations, it can be concluded:

1. R2 valueAccountabilityis 0.158 it means Accountability influenced by Leadership and Motivation of $15.8 \%$ while the rest is influenced by other factors not examined in this study.

2. Path coefficient Leadership is 0.318 with a positive direction, meaning that there is a unidirectional relationship. If Leadership increase by 1 unit then Accountability will increase by 0.318 . 
3. Path coefficient Motivation is 0.132 with a positive direction, meaning that there is a unidirectional relationship. If Motivation increase by 1 unit then Accountability will increase by 0.132 .

The coefficient of determination (R2) is used to determine the magnitude of the ability of endogenous variables to explain the diversity of exogenous variables or in other words to determine the magnitude of the contribution of exogenous variables to endogenous variables. This effect ranges from 0 to 1 , with 1 representing complete predictive accuracy. Because R2 is embraced by various disciplines, researchers must rely on a rule of thumb regarding acceptable $\mathrm{R} 2$, with prediction accuracy rates of 0.75 (strong), 0.50 (moderate), and 0.25 (weak). Here are the results of the R2 analysis:

\section{Table 10 Coefficient of Determination Results (R2)}

\begin{tabular}{|c|c|}
\hline Variable & R Square \\
\hline Accountability & 0.158 \\
\hline
\end{tabular}

Source: Data processed in 2021

The table shows that $\mathrm{nR} 2$ valueAccountabilityis0.158 it means Accountability influenced by Leadership and Motivation by $15.8 \%$ (in the weak category). Q2 Predictive Relevance is used to calculate $\mathrm{R}^{2}$. The $\mathrm{Q}$-square value obtained by using the $R^{2}$ value in the table above using the formulaQ2 = 1- (1-R12) (1-R22), the calculation results are obtained as follows:

Table $11 \mathrm{Q}^{2}$ Predictive Relevance

\begin{tabular}{|c|c|}
\hline Criteria & Results \\
\hline R2Accountability & 0.158 \\
\hline Q2 & 0.158 \\
\hline
\end{tabular}

Source: Data processed in 2021

Based on the table above, the value of Q2 (Q-square predictive relevance) obtained is 0.158 . Because the value is greater than 0 (zero) it meansthe model has a predictive relevance value, where the model used can explain the information contained in the research data by $15.8 \%$

\section{Bootstrapping Hypothesis Testing (Path Analysis)}

The hypotheses tested in this study are:

H1: There is an influence of Leadership on Accountability

$\mathrm{H} 2$ : There is an influence of motivation on Accountability

Hypothesis testing is used to test whether there is an effect of exogenous variables on endogenous variables. The test criteria state that if the P-Value value is < significant alpha $5 \%$ or 0.05 , it means that there is a significant effect of exogenous variables on endogenous variables. The results of the significance and model testing can be seen through the following figures and tables. 
Table 12 Path Coefficient Value

\begin{tabular}{|l|r|r|r|}
\hline & $\begin{array}{c}\text { Original } \\
\text { Sample }(\mathrm{O})\end{array}$ & $\begin{array}{l}\text { T Statistics } \\
(\mid \mathrm{O} / \text { STDEV } \mid)\end{array}$ & $\begin{array}{l}\text { P } \\
\text { Values }\end{array}$ \\
\hline Leadership $\rightarrow$ Accountability & 0.318 & 2,526 & 0.012 \\
\hline Motivation $\rightarrow$ Accountability & 0.132 & 1.136 & 0.256 \\
\hline
\end{tabular}

Source: Data processed in 2021

Based on the table can be explained as follows:

\section{H1: There is an influence of leadership onAccountability}

In the test results listed in the table above, it can be seen that the coefficient Leadership to Accountability is 0.318 (positive direction), T statistics is 2,526, and the $\mathrm{p}$-value is 0.012 . The test results show that the $\mathrm{p}$-value $<0.05$. Then $\mathrm{H} 1$ is accepted, it meansThere is an influence of leadership on Accountability. This result is according to Steawarship Theory (Donaldson \& Davis, 1991). This theory explains that managers or organizational implementers are not concerned with personal interests but prioritize the interests of the principal, in this theory it is explained that management has high honesty and integrity to be responsible to stakeholders and shareholders to maintain public trust. Regarding the research conducted in the school environment, it is clear that the principal in this case is the government or the head of the foundation, while the stakeholders in this study are parents or guardians of students. Based on the previous explanation, it is known that financial accountability is a form of performance appraisal, especially managerial schools, so the concept of accountability uses the basic concept of performance. (Basil \& Kiriinya, 2019), (Widodo, 2017), (Butler, 2016), (Melo et al., 2020)] concluded that leadership is an important factor in creating performance. Based on the results of the factor loading test, it can also be seen that an effective leader is a leader who has the ability to experiment and has the characteristics of being diligent, reliable, ambitious, organized and sympathetic. Leaders who are willing to experiment, the fault is the ability to be able to implement policies to invest existing resources effectively by investing existing resources will encourage employees or subordinates to work well so that organizational accountability can be achieved (Møller, 2003). A sympathetic leader will position himself as someone who is committed to his organization and is able to communicate well with his subordinates (Azis et al., 2019) With a sympathetic nature will also encourage subordinates to behave well. One of the results that can be felt by subordinates if leadership runs effectively is if the leader can encourage his subordinates to want to innovate (Khaola \& Oni, 2020). Leaders who are serving will make their subordinates to grow and succeed in their work environment (Zeeshan et al., 2021). A leader must have the view that the organization he leads is his (Frantz et al., 2020) so that a leader will try to keep that commitment well. One of the reliable leaders is a leader who can actively show openness and availability to communicate and interact with his subordinates, so that subordinates will feel valued by their leaders (Nguyen et al., 2019). An efficient leader can encourage inclusion and empowerment of employees or subordinates so that employees or subordinates can and are willing to perform tasks beyond their obligations (Kuknor \& Bhattacharya, 
2021). Ethics plays a key role in relation to leadership and accountability, leaders must avoid unethical behavior to achieve accountability (Melo et al., 2020).

\section{H2: There is an influence of motivation onAccountability}

In the test results listed in the table above, it can be seen that the coefficient Motivation to Accountability is 0.132 (positive direction), T statistics is 1.136 , and the $\mathrm{p}$-value is 0.256 . The test results show that the p-value $>0.05$. Then $\mathrm{H} 2$ is rejected, it meansThere is no influence of motivation onAccountability. The results of this study are not in line with some other studies. This result is not in accordance with previous studies. conducted by several previous studies show that motivation affects performance as the results of research(Kolk, Berend Van Der, 2019), (Miao et al., 2019), (Do et al., 2020), (Hutagalung, Riama Katarina, 2020), (Petrovsky et al., 2014), (Usman, 2017) Several related studies were used as references in this study, including research conducted by (Kolk, Berend Van Der, 2019) in subsequent studies explained that employee motivation plays one of the most important parts in organizational performance and confidently contributes to its development and prosperity. This unaffected result shows that for school principals as leaders in school organizations, the motivational factor is not a concern for principals to support the achievement of good accountability.

\section{E. CONCLUSION}

There is an influence of leadership on accountability. The ability to experiment and the warm nature of a leader are the main driving factors for a leader to achieve optimal accountability. There is no effect of motivation on accountability.

\section{REFERENCES}

1. Servant Muse, et al. (2017). Manuscript Info Abstract Introduction. ISSN: 23205407. 7(10), 166-172. https://doi.org/10.21474/IJAR01/9818

2. Almquist, R., Grossi, G., van Helden, GJ, \& Reichard, C. (2013). Public sector governance and accountability. Critical Perspectives on Accounting, 24(7-8), 479-487. https://doi.org/10.1016/j.cpa.2012.11.005

3. Azis, E., Prasetio, A. P., Gustyana, T. T., Putril, S. F., \& Rakhmawati, D. (2019). The mediation of intrinsic motivation and affective commitment in the relationship of transformational leadership and employee engagement in technology-based companies. Polish Journal of Management Studies, 20(1), 54-63. https://doi.org/10.17512/pjms.2019.20.1.05

4. Bakalikwira, L., Bananuka, J., Kaawaase Kigongo, T., Musimenta, D., \& Mukyala, V. (2017). Accountability in the public health care systems: A developing economy perspective. Cogent Business and Management, 4(1). https://doi.org/10.1080/23311975.2017.1334995

5. Basil, KM, \& Kiriinya, SN (2019). Leadership Styles and Performance of Selected Government Ministries in Embu County, Kenya. 6(2), 224-229.

6. Brender, N., Yzeiraj, B., \& Dupuy, F. (2017). Risk and accountability: Drivers for 
change in network governance. The case of school restaurants governance in a Swiss city. Cogent Business and Management, 4(1). https://doi.org/10.1080/23311975.2017.1384636

7. Butler, C. (2016). Followers' personality, transformational leadership and performance. https://doi.org/10.1108/SBM-09-2011-0074

8. Buyema, WM (2016). Effect of Institutional Leadership on Performance of National Government.

9. Cetindamar, D. (2018). Designed by law: Purpose, accountability, and transparency at benefit corporations. Cogent Business and Management, 5(1). https://doi.org/10.1080/23311975.2018.1423787

10. Chen, CA, \& Hsieh, CW (2015). Knowledge sharing motivation in the public sector: the role of public service motivation. International Review of Administrative Sciences, 81(4), 812-832. https://doi.org/10.1177/0020852314558032

11. Colquitt, JA, Lepine, JA, \& Wesson, MJ (2019). Organizational Behavior Improving Performance and Commitment in The Workplace.

12. Do, AD, Pham, NT, Bui, HP, \& Vu, DT (2020). Impact of Motivational Factors on the Work Results of Lecturers at Vietnam National University, Hanoi*. 7(8), 425433. https://doi.org/10.13106/jafeb.2020.vol7.no8.425

13. Donaldson, L., \& Davis, J. H. (1991). Stewardship Theory or Agency Theory: CEO Governance and Shareholder Returns. Australian Journal of Management, 16(1), 4964. https://doi.org/10.1177/031289629101600103

14. Dubrin, \& Andrew J. (2019). Fundamentals of Organizational Behavior.

15. Dwi Widyani, A. A., Landra, N., Sudja, N., Ximenes, M., \& Sarmawa, I. W. G. (2020). The role of ethical behavior and entrepreneurial leadership to improve organizational performance. Cogent Business and Management, 7(1). https://doi.org/10.1080/23311975.2020.1747827

16. Edison, E., Anwar, Y., \& Komariyah, I. (2018). Human Resource Management. Bandung: Alfabeta.

17. Fadjar, A., Rohaeti, T., \& Nurdiani, D. (2020). Transparency, Public Accountability and Village Finance. PalArch's Journal of Archaeology of Egypt/Egyptology, 17(10), 3698-3707.

18. Frantz, J., Lawack, V., \& Rhoda, A. (2020). Reflections of academic and professional leaders on leadership in a higher education institution. SA Journal of Human Resource Management, 18, 1-6. https://doi.org/10.4102/sajhrm.v18i0.1373

19. Han, Y., \& Perry, J. L. (2019). Public Employee Accountability: Development of a Five-Dimensional Scale. Academy of Management Proceedings, 2019(1), 14043. https://doi.org/10.5465/ambpp.2019.14043abstract

20. Hassan, S., \& Hatmaker, D. M. (2016). Leadership and Performance of Public Employees: Effects of the Quality and Characteristics of Manager-Employee Relationships. 1127-1155. https://doi.org/10.1093/jopart/muu002

21. Hudaya, M., Smark, C., Watts, T., \& Silaen, P. (2015). The use of accountability reports and the accountability forum: Evidence from an Indonesian local government. Australasian Accounting, Business and Finance Journal, 9(4), 57-70. 
https://doi.org/10.14453/aabfj.v9i4.5

22. Hutagalung, R. K., et al. (2020). The Effect of Competence , Work Ethic, Work Discipline, and Work Motivation on Performance of Government Employees in Mentawai Islands District Health Office. 5(8), 387-396.

23. Jones, G., \& Beattie, C. (2015). Local government internal audit compliance. Australasian Accounting, Business and Finance Journal, 9(3), 59-71. https://doi.org/10.14453/aabfj.v9i3.5

24. Khaola, P. P., \& Oni, F. A. (2020). The influence of school principals' leadership behavior and act of fairness on innovative work behaviors amongst teachers. $S A$ Journal of Human Resource Management, 18, 1-8. https://doi.org/10.4102/sajhrm.v18i0.1417

25. Khuwaja, U., Ahmed, K., Abid, G., \& Adeel, A. (2020). Leadership and employee attitudes: The mediating role of perception of organizational politics. Cogent Business and Management, 7(1). https://doi.org/10.1080/23311975.2020.1720066

26. Kolk, Berend Van Der, et al. (2019). The Impact of Management Control on Employee Motivation and Performance in the Public Sector 8180. https://doi.org/10.1080/09638180.2018.1553728

27. Kuknor, S., \& Bhattacharya, S. (2021). Organizational inclusion and leadership in times of global crisis. Australasian Accounting, Business and Finance Journal, 15(1 Special Issue), 93-112. https://doi.org/10.14453/aabfj.v15i1.7

28. Leithwood, K., Steinbach, R., \& Jantzi, D. (2002). School leadership and teachers' motivation to implement accountability policies. Educational Administration Quarterly, 38(1), 94-119.

29. Mahmudi. (2013). Public Sector Performance Management. YKPN College of Management Science.

30. Mardiasmo. (2002). Public sector accounting. Yogyakarta: ANDI.

31. Melo, PN, Martins, A., \& Pereira, M. (2020). the Relationship Between Leadership and Accountability: a Review and Synthesis of the Research. Journal of Entrepreneurship Education, 23(6).

32. Miao, Q., Eva, N., Newman, A., \& Schwarz, G. (2019). Public service motivation and performance: The role of organizational identification. 0962, 954-962. https://doi.org/10.1080/09540962.2018.1556004

33. Møller, J. (2003). has become a popular concept in this regard. The meaning of the term is, however, more elusive and may be difficult to put into practice. In the English language, it is possible to lexically distinguish between. 1-8.

34. Nguyen, P. V., Le, H. T. N., Trinh, T. V. A., \& Do, H. T. S. (2019). The effects of inclusive leadership on job performance through mediators. Asian Academy of Management Journal, 24(2), 63-94. https://doi.org/10.21315/aamj2019.24.2.4

35. O'Donnell, G. (1998). Horizontal accountability in new democracies. Journal of Democracy, 9(3), 125-126. https://doi.org/10.1353/jod.1998.0051

36. Pancasila, Irwan, et al. (2020). Effects of Work Motivation and Leadership toward Work Satisfaction and Employee Performance: Evidence from Indonesia. 7(6), 387397. https://doi.org/10.13106/jafeb.2020.vol7.no6.387 
37. Petrovsky, N., Ritz, A., Petrovsky, N., \& Ritz, A. (2014). Public service motivation and performance: a critical perspective Public service motivation and performance: a critical perspective. https://doi.org/10.1108/EBHRM-07-2013-0020

38. Quayle, B., Sciulli, N., \& Wilson-Evered, E. (2020). Accountable to who, to whom, for what and how? Unpacking accountability in local government response to climate change. Australasian Accounting, Business and Finance Journal, 14(3), 56-74. https://doi.org/10.14453/aabfj.v14i3.5

39. Grace. (2018). Public Administration and Accountability. Yogyakarta: ANDI.

40. Robbins, S. P., \& Timothy, P. J. (2018). Essentials of Organizational Behavior.

41. Rufus, OS, \& O, GC (2019). Accountability and Public Sector Performance in the Third World Country: A Case Study of Nigeria. International Journal of Trends in Scientific Research and Development, 3(3), 218-225. https://doi.org/10.31142/ijtsrd21748

42. Said, J., Alam, MM, \& Bin Abd Aziz, MA (2015). Public accountability system: Empirical assessment of the public sector of Malaysia. Asian Journal of Scientific Research, 8(2), 225-236. https://doi.org/10.3923/ajsr.2015.225.236

43. Schillemans, T. (2016). Calibrating Public Sector Accountability: Translating experimental findings to public sector accountability. Public Management Review, 18(9), 1400-1420. https://doi.org/10.1080/14719037.2015.1112423

44. Sofyani, H., Riyadh, HA, \& Fahlevi, H. (2020). Improving service quality, accountability and transparency of local government: The intervening role of information technology governance. Cogent Business and Management, 7(1). https://doi.org/10.1080/23311975.2020.1735690

45. Susilo, DE et al. (2019). The effect of employee commitment, culture, and leadership style on good governance performance of Jombang District government (Indonesia).

46. Sutrisno, E. (2020). Human Resource Management (11th ed.). date.

47. Suwatno, \& Priansa, D. J. (2018). HR Management in Public and Business Organizations. Alphabet.

48. Tran, YT, \& Nguyen, NP (2020). The impact of the performance measurement system on the organizational performance of the public sector in a transition economy: Is public accountability a missing link? Cogent Business and Management, 7(1). https://doi.org/10.1080/23311975.2020.1792669

49. Usman, A. and Herman. (2017). Influence of Motivation on the Performance of Government Employees. 149(Icest), 46-48.

50. Widodo, DS et al. (2017). Analysis of Organizational Performance : Predictors of Transformational Leadership Style, Services Leadership Style and Organizational Learning ( Studies in Jakarta Government ). 167-182.

51. Wijaya, J. H., Abiyyu, R., Sari, S. A., \& Marion, S. N. (2021). The Effects of Transparency, Accountability, and Participation on the Discretion of Netizens on Social Media (A Case Study on Facebook Users ). 18(1), 740-751.

52. Zabolotniaia, M., Cheng, Z., \& Dacko-Pikiewicz, Z. (2019). Influence of leadership style on employees' innovative activity. Polish Journal of Management Studies, 20(1), 478-496. https://doi.org/10.17512/pjms.2019.20.1.41 
53. Zeeshan, S., Ng, S. I., Ho, J. A., \& Jantan, A. H. (2021). Assessing the impact of servant leadership on employee engagement through the mediating role of selfefficacy in the Pakistani banking sector. Cogent Business and Management, 8(1). https://doi.org/10.1080/23311975.2021.1963029. 